\title{
The place of African belief and germ theory on the causes of human diseases
}

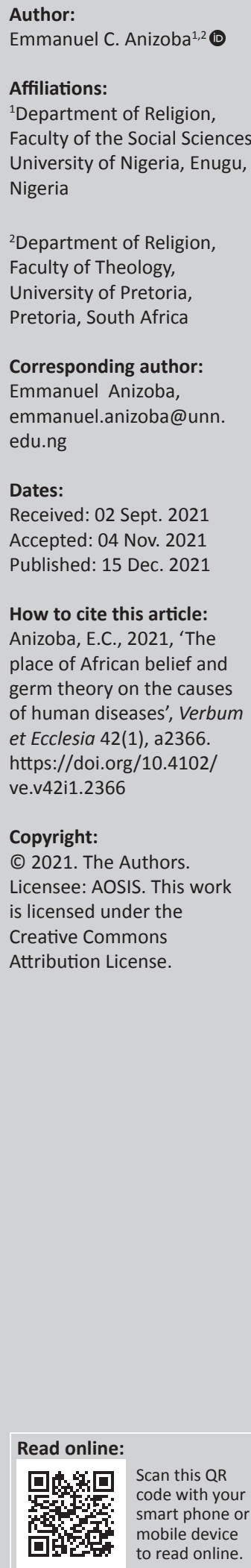

This study looks into the African belief about the mystical causes of diseases and the tenets of Western germ theory. Despite widespread Western medical practices, African people still strongly believe in the mystical causes of diseases. This reveals that as far as the African traditional belief is concerned, Western germ theory cannot satisfy the African belief in the causes of diseases. This is as a result of some of the diseases defying Western healing. The study adopts a qualitative phenomenological research design and descriptive method for data analysis. Personal interview forms a primary source of data collection while the secondary source includes library resources. The study observes that some mystical agents in African cosmology, such as witches and sorcerers, ogbanje, and breaking of taboos are responsible for untimely deaths, infliction of diseases to humankind and other related ailments which are believed to be traditional in nature.

Intradisciplinary and/or interdisciplinary implications: The study recommends that hospitals and healthcare centres, within and outside Africa, should take into consideration the mystical agents as well as the pathogenic agents for good and efficient healing.

Keywords: African mystical belief; germ theory; witchcraft; causes of disease; medication.

\section{Introduction}

Medical dictionaries have not articulated a satisfactory definition of the term 'disease'. However, according to the World Health Organization (1946), disease is simply the opposite of health. The WHO (1946:n.p.) maintained that health is 'a state of complete physical, mental and social wellbeing, not merely the absence of disease or infirmity'. According to Wehmeier (2000), diseases are illnesses which affect a person, animal or plant. Therefore, diseases are those illnesses that affect persons, animals or plants that may lead them to extinction. Western theory of germs as a cause of disease states that microorganisms are the principal causative agents of diseases. These microorganisms, according to Henderson and Brock (1999), are considered too small to be seen without magnification of microscopes. Accordingly, both Waller (2004) and Last (2007) agreed that these small organisms invade human beings, animals and other living organisms, as the case may be. Within their hosts, they can cause diseases as they grow and reproduce. In this regard, Henderson and Brock (1999) believed that these microorganisms may be called germs which refer to not just a bacterium, but to any type of micro-organism, especially one which causes disease. These microorganisms may include: protista, fungi, viruses, prions, or viroids. The microorganisms that cause disease are called pathogens, and the diseases they cause are technically called infectious diseases. Based on the definition of germ theory, one can comprehend that it emphasises the Western notion which suggests that diseases are caused by germs for the purpose of this work.

Disease is one of the main issues and challenges that human beings experience across generations. It seems to have caused more deaths and sorrows than all other life-threatening factors such as car accidents or plane crashes. Human beings in one way or the other fall sick, and seek remedies depending on their choice of treatment (trado-medical or western medical). Although African traditional religion (ATR) is not against the western healing process, its followers believe that there are some diseases that western medicine cannot cure such as elephantiasis, epilepsy, and so on. They are also of the opinion that certain psychological conditions such as depression, catatonic schizophrenia, psychosis, among others are treatable via traditional healing. Therefore, some of these diseases require spiritual attention as sometimes practised in churches and herbal homes. Furthermore, there are some diseases that are said to have defied both orthodox and traditional healing such as HIV or AIDS, Ebola, and COVID-19. Consequently, the affected individual has to manage the sickness. 
Against this backdrop, human beings in every age have had to devise various means of combating diseases. Two of the major and most universally accepted methods of combating diseases are mystical and orthodox. It is believed in ATR that there are certain mystic forces in the universe which can be tapped and utilised to bring about some effects, good and bad (Omoregbe 1999). Omoregbe observed that some people have access to these forces (supernatural powers) and make use of them. While some people (e.g. priestphysicians) utilise these powers for good purposes, such as healing and solving difficult problems, some use them for evil purposes, such as causing harm and mysterious sicknesses and diseases to other people, which sometimes lead to death. These may be witches and sorcerers who cause havoc by manipulating mystical forces. In this regard, the African traditional concept of the causes of diseases and sickness is always tied in to gods, divinities or often spiritual forces. Thus, a spiritual intervention is considered as a necessary requirement for the treatment of diseases in African belief system.

On the other hand, the Western concept of the causes of diseases and healing practices is quite different from those of ATR. According to Last (2007), Western concept of the causes of diseases is mostly based on 'germ theory'. This theory, according to Waller (2004), supposes that diseases can be caused by microorganisms which may be called germs. These germs enter the human body and cause diseases of many kinds.

In the African world, there are two methods of combating and battling with diseases: mystical/spiritual and orthodoxy. As a result, it is difficult to ascertain the true causes of a disease. For some people, diseases are caused by mystical agents like witchcraft or sorcery, while many believe in germ theory. Despite the widespread prevalence of Western healing practices globally, there is a steadfast belief in Igbos even today that diseases are caused mystically, as posited by Ilogu (1987) and Ngong (2009).

In this context, the question then is: Are diseases caused by mystical forces according to the African belief or by germs? To answer this question, this research wants to perform a comparative analysis of mystical causes of diseases and that of western germ theory in contemporary African belief system. It can then be argued whether diseases are caused solely by mystical forces, or by germs, or by both. The foremost duty of a medicine healer (herbalist or dibia), is to find out the mystical cause of a given disease before treating it through the use of appropriate herbs. On the contrary, the western germ theory links every disease with a particular causative agent such as virus, bacteria and other pathogens. Since science and modern healing practices uphold this to be scientifically correct, it is then confusing to place certain diseases like HIV and AIDS, Ebola, COVID-19 and so on, that defy both traditional and western healings. One may ask why the beliefs in mystical causes of diseases hold sway among the Igbo even in the age of Western germ theory.
The comparative analysis of western germ theory and mystical causes of diseases calls for a qualitative research approach. As a qualitative study, phenomenological research designs were adopted in the study. Phenomenological method, according to Christopher (1989) and Madu (1996) describes a study as an attempt to understand people's perceptions, perspectives and understandings of a particular situation (or phenomenon). The objective of phenomenology is the direct investigation and description of phenomena as consciously experienced, without theories about their causal explanations or their objective reality. It therefore seeks to understand how people construct meaning. According to Christopher (1989) and Madu (1996), phenomenological research study attempts an interpretation of data as they are. Accordingly, Madu (1996) stated that the business of phenomenology of religion is to provide an analytic description of these data presented by different religious traditions in order to find out where they converge or separate. This idea is echoed by Essien (2014):

Phenomenology is a careful, analytic description. It lets one to see that which shows itself (namely the phenomenon) by removing as far as possible concealments, distraction and whatever else might prevent us from seeing the phenomenon as it actually gives itself. (p. 10)

The reason behind adopting this method is to allow the data collected to speak for themselves, without any interference. Some of the mystical causes of diseases (witchcraft, magic and medicine) are examined through direct interviews with self-confirmed witches and wizards, traditional medical practitioners, and medical doctors. Germ theory is stated as it is, and both theories are critically analysed through people's perception. Data collection for this study is based on both primary and secondary sources, given the qualitative nature of the study. The primary source of data for the study is personal interviews (pers. comm.), and secondary sources comprise library resources which include: journal articles, materials from websites, newspapers, and so on. Adescriptive method of data analysis is used in the study.

\section{Germs as disease causative agents}

According to Egger (2008), germ theory of disease states that many diseases are caused by microorganisms that can be seen with or without the aid of a microscope. Germ theory proposed by Louis Pasteur (1822-1895) and Robert Koch (1843-1910), states that human diseases in their entirety are either caused by specific microbes or germs. These microorganisms include bacteria, viruses, and fungi. Although microorganisms cause diseases, several environmental and genetic factors may predispose a host or influence the severity of the infections. For example, in a host that is immunecompromised (e.g. because of HIV or old age), an infection may comparatively result in severe outcomes than in individuals who are immune-competent.

Agostino Bassi in the early 1800s conducted a series of experiments which demonstrated that a disease afflicting silkworms at the time was caused by a parasite. Bassi 
theorised that diseases in humans and animals were also caused by microorganisms. His work served to influence Louis Pasteur, a French chemist-turned-microbiologist, who proved the existence of microbes in air. Pasteur is accredited with the germ theory of disease following his experiments demonstrating the relationship between microorganisms and diseases. His pioneering studies laid the foundation for the modern-day understanding of diseases, their etiology, as well as vaccine development. Baxter (2001), while tracing the origin of germ theory, observed that diseases could spread by 'seed-like entities'. The germ theory views diseases in terms of a causal network similar to that of Italian physician Girolamo Fracastoro, but with much more detail regarding the nature of germs and possible treatments.

Organisms that cause diseases inside the human body are called pathogens; bacteria and viruses are the commonlyknown pathogens. Fungi, protozoas and parasites can also cause disease. Infectious diseases are typically classified as bacterial, viral, protozoal and so on. Knowing what bacteria is responsible for a particular disease indicates what antibiotic treatment to apply. Diseases are called infectious or communicable if pathogens can be transmitted from one person to another. A germ is a very small organism that causes disease. It is a small mass of living substance capable of developing into an organism or one of its parts. Fenner and Gibbs (eds. 1988) observed that microorganisms, especially ones that causes disease, are found all over the world in all kinds of places. They can invade plants, animals, and humans, and sometimes can make one sick. By sickness, the researcher refers to a state whereby someone is ill, or ill health. This also refers to certain psychological conditions which humans may suffer from.

While tracing the origin of germ theory, Waller (2004), maintained that the propounding of germ theory with special reference to the works of Louis Pasteur and Robert Koch, opened the door to research into the identification of diseasecausing germs and potential life-saving treatments. Germ theory states that many diseases are caused by the presence and actions of specific microorganisms within the body (bacteria). Worboys (2008) declared that this theory superseded the once prevailing Miasma and Contagion theories of disease, and radically changed the practice of medicine. Other scholars such as Nutton (1983), defined germ theory as the theory which states that diseases are caused by microorganisms. These organisms, according to him, are too small to see without magnification. They invade humans, animals and other living hosts. Their growth and reproduction within their hosts can cause a disease. He pointed out that 'germ' may refer to not just a bacterium but to any type of microorganism, especially one which causes disease, such as protists, fungi, viruses, prions, or viroids. Thus, microorganisms that cause diseases are called pathogens and the diseases they cause are called infectious diseases. Nutton (1983:15) also maintained that environmental and hereditary factors often influence not only the severity of the disease causation but also whether a potential host individual becomes infected when exposed to the pathogen.
This is evident as dirty and non-sanitised environments breed bacteria and enhance the spread of diseases.

Nutton was not alone in this submission. Porter (1997) highlighted that germ theory is one of the most wellestablished principles in medicine and epidemiology, as well as a cornerstone for public sanitation policy. Porter (1997:12) encouraged one to always keep the environment clean in order to render tit non-conducive for breeding of microorganisms that cause diseases. However, some scholars were against the germ theory. Scholars like Fielder (2001), who propounded germ theory denialism, believes that germs do not cause infectious diseases, and that the germ theory of disease is wrong. Madigan and Martinko (2006) proposed an obsolete variation of germ theory denialism known as 'terrain theory'. They postulated that germs are not the causative agents of diseases, rather diseases attract germs and can cause one's diseases to become terminal.

Maher (2009), an alternative medicine advocate, denied the validity of germ theory pointing out that 'micro-organisms are symptoms rather than causes of illness'. Maher's theory postulated that germs are not the only causative agents of diseases, but that other genetic factors are also involved (Alcais, Abel \& Casanova 2010). According to the theory above, one can inherit diseases from one's parents irrespective of a healthy regime and clean environment one maintains. According to Wallach, Lan and Schrauzer (2014), epigenetics presupposes that alternations in gene expression can be caused by factors other than changes in the DNA. DNA can be defined as an acid in the chromosomes in the centre of the cells of living things. It determines the particular structure and functions of every cell and is responsible for characteristics being passed on from parents to their children.

\section{Some mystical causes of human diseases in African traditional belief system}

In African traditional belief, there is a widely accepted notion that certain diseases as well as sicknesses are brought on by some mystical agents which may include witchcraft, witches, wizards, sorcerers, and fear. In other words, in African traditional belief, nothing happens without a cause. According to Frazer (1992), the belief in witchcraft is not specific to Africa, but is worldwide. It is to be noted, however, that Frazer's theory was propounded in the 19th century. While the researcher acknowledges the date of this theory, he still finds it relevant to issues of witchcraft today in Africa. Witchcraft is said to have a controversial meaning and its usage and application varies along cultural lines. In African worldview, witchcraft basically involves the use of magic, sorcery or supernatural powers to arrive at a desired end. Some cultures in Africa believe that witches can cause any of the following health conditions: madness, hypertension, swollen legs, and epilepsy. One might want to ask: Why is the belief in witchcraft rampant in African belief? And why is it rampant to the extent that it affects their approaches to 
problems such as disease causations? Nowadays, many people link and attribute natural experiences, social, political, economic and health problems to witchcraft. This is evidently observed in mob reactions and activities all around Africa, especially among the Igbo people of the Eastern part of Nigeria.

Once a complex and strange activity related to sickness and disease manifests, people take shield under the witchcraft explanation model. According to this model, it can be perceived that it is the means of disease causation worldwide and more especially in Africa. On the other hand, the pervasive stigmatisation of witchcraft was perceived to be an upshot of the lack of exposure or illiteracy. It has been argued by Anizoba, Okereke and Ngawuchu (2020) that illiteracy is responsible for this phenomenon. This is as a result of people not properly informed. Because, if they were, physical effects wouldn't be attributed to non-physical causes and so on. However, it would be unwise to pinpoint illiteracy as the sole reason for the excessive appropriation of misfortunes, diseases and sicknesses to witchcraft. Reflecting on witchcraft belief among Africans, Radford (2010) is of the opinion that ignorance and fear play a strong role in its development and growth. It has not only been used to explain the cause of bad harvests, illnesses, deaths and determination of farmlands; it also serves as a social, psychological and moral restraint. Because of the belief that witches or wizards are said to have the powers to bring about harm to members of certain families or community members, in a closely-knit community, the said person was perceived as very dangerous.

According to Informant 1 (pers. comm., 04 March 2019), Africans believe that ancestral curses cause extreme harm to some families even though they try to break the curse, as there is power in a spoken word that is seasoned with magical power. Ancestral curses have crippled activities of certain people entirely. They have rendered people useless and worthless in such a way that their existence on earth makes no meaning. The negative effect of ancestral curses culturally, socially and otherwise has relegated people to complete failure in as much as their destinies have been hijacked by the so-called unscrupulous ancestors. In the full realisation of the negative consequences of curse(s), the idea of negative utterances with magic power are expressions never to be made in recent times. This is the reason why people now profess positive statements rather than negative comments. Africans have realised that negative expressions are accompanied with consequences which can be quite destructive.

'Ogbanje' also known as 'Abiku' in the Yoruba language, refers to those alleged spirit children who are brought into the world only to die young, go back to the spirit world and return back again, born via the same woman. The ogbanje spirit does evil mainly to people and supersedes the good. The good done by the ogbanje spirit is a cover up. The ogbanje spirit temporarily enters this world; it comes and goes through children who are born. It is also connected to women who deliver children, repeatedly dying and reincarnating into this world. When the children are identified as ogbanjes, they are marked to authenticate whether they are the children who kept reincarnating. The possession of the ogbanje spirit cuts across all sexes, thus incorporating both boys and girls. Any girl who is known to be possessed by the ogbanje spirit finds it very difficult to marry because the spirit is accompanied with wastage and havoc. Men who are possessed by the ogbanje spirit find it difficult to communicate with their close friends. It is an evil spirit that comes to wreak havoc on someone. For instance, a child who is possessed by the ogbanje spirit usually becomes sick. Such children see to it that the income of their parents dwindle. If that particular child discovers that the parents have money, the sickness will start again until the parents spend the money trying to heal the child. Thereafter, the child becomes strong and healthy.

Breaking of taboos and oath is believed to cause disease. According to Wehmeier (2000), taboo is described as a custom of a particular culture that prevents or prohibits people from talking about, or engaging in a particular thing or subject that is deemed socially or religiously sacred. An oath or a formal statement is a promise to do something, or an affirmation of the veracity of something. ${ }^{1}$

\section{Poisoning in African belief system as a means of disease causation}

Poisoning is a means of disease causation in African belief, particularly what is called mystical poisoning. Mystical poisoning are two words which should be explained separately before bringing them together. Mystical is derived from the word mystery. Jantzen (1994) classified mystical experiences and their characteristics in different religions and mystical traditions; he queried, to what extent mystical experiences were conditioned by a mystic's language and culture, and whether mystical experiences furnished evidence for the truth of their contents. On the other hand, Turner (1996) questioned the priority on experience in favour of investigating the whole mystical complex. Bouyer (1981) summed it up by asserting that:

The term mysticism typically denotes a complex of beliefs and practices related to the personal experience of the divine. Much, although not all, mystical thought and practice derives from or draws upon formal religious doctrines, emphasizing reflective, introspective, and meditative practices as the keys to cultivating perception and awareness that will ultimately lead to knowledge of and communion with the divine. (p. 14)

Mystery is something that is very difficult to understand or to explain and by extension, mystical is when something has spiritual power or qualities that are very difficult to understand or to explain. Thus, what is considered as the belief in mystery can be defined as a belief in a spiritual real

1.In his own contribution, Informant 2 (pers. comm., 04 March 2019) observed that taboo in the African context goes with the prohibition of some practices and some thins in the African context goes with the prohibition of some practices and some things were not allowed to be said publicly. The taboo is a well-known cultural and religious custom allover Africa. Even when white people tried to westernise Africa, the fact remains that African culture is unique and complex to the extent that the Europeans made case studies of our culture and even stole some artefacts in order to explore the significance of our culture. 
having access to the visible reality and the power to influence it. There is no doubt that there are mystical forces and powers that are beyond reasons and senses; rather mystics require prayers and meditation.

Poisoning refers to having swallowed or absorbed poison. It is also the act of killing or harming somebody/something by giving poison. Mystical poisoning is the act of killing people through food poisoning. There are different substances in our surroundings which can be used for poisoning which cause diseases like persistent headache, unidentified fever and so on. Sometimes these substances may lead to death of people instantaneously It is easy to create a poisonous concoction. It is all about knowing the procedures and following the rudiments. On the other hand, mystical poisoning can also be manipulated in the realm of spiritual power to harm whoever is a target of destruction. Mystical poisoning can be done through physical state, spiritual state, and otherwise. The ones perpetrated by physical processes are usually through food. When such food is eaten, it leads to physical harm like liver damage, constant coughing otherwise known as tuberculosis, or death while that of spiritual poisoning is manipulated through metaphysical process. It could be done either through air or through incantations.

Mystical poisoning has no connection with medical panacea except worsening the situation. A patient suffering from mystical poisoning should never seek medical diagnosis and treatment. This is why some mystical ailments can never be tested and detected by laboratory experiments because of their inherent diabolical nature. When mystical poisoning is discovered, it is expedient to seek traditional medicines and other concoctions of herbs and roots. Some requires the services of a witch doctor while others require soothsaying.

Fear is the feeling one gets when one is afraid or worried that something bad is going to happen. It is usually a thing that one is scared of, or is the unknown which has the tendency to terrorise. It could also be a very strong uncontrollable and unpleasant emotion triggered by actual or perceived harm or threat. Toochukwu (pers. comm., 09 July 2019) contends that if someone constantly perceives of falling ill of a particular ailment or disease, there is no doubt that such a person will definitely fall sick, because of pathological fear inherent in the person.

\section{African belief and germ theory on causes of diseases: An evaluation}

Cultural theory of mystical causes of disease and sickness is dominant among Africans. According to Vander-Zanden (1990), beliefs in witchcraft influence persons whether or not they seek formal treatment and their response to it. It was observed that people living in some communities often share folk beliefs that do not correspond to those of modern medical explanations and this keeps them from seeking modern medical treatment. For instance, Informant 3 (pers. comm.,
04 September 2018) observed that the beliefs in mystical causation of disease theory are universally linked to the beliefs and practices of witchcraft or sorcery. This cultural theory of disease and sickness is dominant among Africans. Witchcraft theory, according to Etobe (2002:10), is used to explain mystical causes of diseases as it provides individuals and society 'the feeling and assumption that individuals are only hated and afflicted with illness by evil men'. It makes people believe that their sicknesses and diseases are caused by external manipulations by others.

Informant 4 (pers. comm., 04 October 2019) states that witches could practise their wicked art only at midnight; deaths, natural disasters, and epidemics - everything was blamed on witches. According to Informant 5 (pers. comm., 20 October 2019), voluntary claims of witchcraft reveal only a state of madness. A person cannot be in possession of something that does not exist. She maintained that witchcraft merely reflects the real world. In addition, Idowu (2001:34) argued that the fact remains that even intellectuals still believe in the existence of people who 'fly-by-night' or have four eyes to inflict people with sickness and disease, and cause havoc. This theory makes it difficult for ardent believers in witchcraft to accept orthodox healing when ill. Thus, they prefer to visit spiritualists, herbalists and traditional healers who are believed to possess some supernatural powers that can aid their recovery. According to Informant 6 (pers. comm., 03 October 2019), witchcraft is the use of magic powers, especially evil ones, to make things happen. It involves the use of supernatural power to manipulate, foretell or estimate some happenings (either positively or negatively) on the basis of mystical knowledge. Undoubtedly, witchcraft is a global phenomenon except that the mode of operation differs from region to region, locally to internationally. The concept of witchcraft is traceable to the quest for mystical power to manipulate fortunes, protection, destruction, invocation, harm, cultic ceremonies, and enchantment as to create a magical result. According to Informant 7 (pers. comm., 12 February 2020), ancestral curses sometimes fall on a group or a family which can be traced to the evil committed by their forebears or forefathers.

On the other hand, a medical practitioner at the University of Nigeria Nsukka Teaching Hospital (UNTH) Enugu, Informant 8 (pers. comm., 04 January 2020) said that germs normally spread through various channels to cause sicknesses and diseases to humankind. According to him, germs live anywhere they can find warmth, food and moisture. Farber (2014) asserted that many people who think that bacteria and viruses do not exist are still abound. They view bacteria and viruses as mere optical illusions created by microscope lenses. A significant number of people, as he reiterated, deny their medical importance. As seen from the works reviewed so far, some are of the view that germs cause diseases while some maintain that bacteria and viruses are symptoms of diseases rather than the cause; finding a hospitable environment in the ill patient. Anizoba et al. (2020) admitted that germs cause the symptoms of disease, but were of the 
view that the real cause is some weakness in the body defences. This creates an impression that vaccines and other preventive measures are pointless. The scientific research into the causative agents of diseases is on-going. It will be unwise to conclude that diseases originate from a peculiar source alone. Sometimes a person's body system may have germs as the causative agents of their diseases while others may owe theirs to genes or epigenetics as the case may be. Science in the near future will still stumble unto other causes of diseases. Contemporarily, the belief that germs cause diseases is scientifically widely accepted. In Nigeria, for example, it has been broadly accepted in the medical and science worlds that germs do cause diseases. Therefore, the germ theory of disease cause is scientifically proven but among many adherents of traditional religion, there is much more to disease causation than just germs.

\section{Recommendation}

In view of the findings of this research work, it is recommended that hospitals and healthcare centres within Africa, should recognise the mystical agents such as witchcraft, witch doctors, superstitions, breaking of oaths, ancestral curses, fear, and so on, of disease causations as well as pathogenic agents such as bacteria, viruses, protozoa, and so on, as reflected in germ theory for proper and adequate healing. The Nigerian Herbalist Association should let their members know that there are pathogenic agents, such as bacteria, viruses, fungi, protozoa etc., that also cause disease. The Federal Government of Nigeria and others should make a law that will support the employment of mystical experts in government and private hospitals in the country. These mystical experts such as necromancers, witchdoctors and herbalists among others, will take charge of the sickness and diseases associated with mystical causes for holistic diagnosis and proper treatment and healing. By implication, this work recommends that both approaches (germ theory and mystical causes) should be adopted in healing diseases because both serve different functions. Parents as first 'teachers' of their children should teach them right from home about the pathogenic agents of disease causation as reflected in germ theory and how some cultural agents otherwise known as mystical agents can also make individuals susceptible to diseases.

Curriculum planners should integrate 'the multifactorial nature of diseases' into the school biology curriculum for secondary school students as well as tertiary institutions to have broad knowledge about diseases, their causative agents and preventions. By so doing, awareness will be created right from the early days in school to adulthood. People should be free to visit both the medical practitioners as well as the traditional doctors to receive proper healing when they are sick. This is because some religious beliefs and practices are against western healing process while others are against traditional ways of healing by virtue of their religious beliefs and practices. Based on the findings, it is clear that there are mainly two kinds of beliefs on the causation of diseases, namely the belief in the mystical causation of diseases in the African traditional worldview as well as belief in the pathogenic agents that cause diseases as germ theory stipulates. The study advises for the need to consider both mystical doctors as well as western doctors when one is faced with health challenges. Finally, the study recommends an integration of the mystical and western doctors in our tertiary institutions to ensure proper documentations and continuity in knowledge on chronic diseases.

\section{Conclusion}

The study examined different aspects of the traditional beliefs in the mystical causation of diseases and western germ theory of disease causation with a view to explore their merits and demerits in the treatment of diseases. In ATR beliefs, diseases are believed to be products of mystical forces. These mystical forces can be conjured and directed to attack humans in forms of diseases. According to the ATR belief system, it is believed that all diseases are caused by some unseen forces or agents. These, as discussed in the work, include ancestral curse, manipulation by wicked and evil people, witches and sorcerers, poison and, so on. Hence, when diseases strike, it is always customary to seek the services of medicine healers otherwise called dibia in Igbo language to find out through divination, the forces behind the diseases people suffer from. Even in contemporary times, this is still greatly practised even among the educated and enlightened people. As has been discussed, this is because of the African belief system which indicates that diseases are caused by human or mystical agents. While many Africans today may accept germ theory, they are also interested in what mystical forces that cause these germs to infect people.

Conversely, the western germ theory links every disease with a particular causative agent - viruses, bacteria and other pathogens. This means that there is no room for the belief in ancestral curses, magic, ogbanje, fear, breaking of taboos, and so on as causes of diseases as the Igbo people see it. Hence it can be argued that while the traditional belief in the mystical causes of diseases in the ATR can be said to be unscientific, that of western germ theory is scientific and suits the modern ways of thinking and belief. But critically speaking, the belief in germ theory as the principal cause of diseases leaves much to be desired. In today's African world, there are diseases which have defied western medication and whose causes seem more mystical than scientific. In Igboland, South Eastern Nigeria, for example, there have been cases where diseases defied western medical practices and sometimes, medical practitioners advise patients to seek traditional help, thereby, proving the prevalence of the African belief in the mystical causes of diseases.

\section{Acknowledgements}

The author would like to acknowledge Dr Kingsley Uwaegbute and Dr Damian Odoh, who contributed immensely on the background of this study. The author also 
acknowledges the financial help rendered by Prof. Jaco Beyers, (Head of Department: Religion Studies, Faculty of Theology, University of Pretoria), enabling the publication of this work.

\section{Competing interests}

The author declares that he has no financial or personal relationships that may have inappropriately influenced him in writing this article.

\section{Author's contributions}

E.C.A. is the sole author of this article.

\section{Ethical considerations}

This article followed all ethical standards for research without direct contact with human or animal subjects.

\section{Funding information}

This research received no specific grant from any funding agency in the public, commercial, or not-for-profit sectors.

\section{Data availability}

Data sharing is not applicable to this article as no new data were created or analysed in this study.

\section{Disclaimer}

The views and opinions expressed in this article are those of the author and do not necessarily reflect the official policy or position of any affiliated agency of the author, and the publisher.

\section{References}

Alcais, A., Abel. L. \& Casanova, J.L., 2010 'Human genetics of infectious diseases', in M.R. Speicher, S.E. Antonarakis \& A.G. Motulsky (eds.), Vogel and Motulsky's human genetics: Problems and approaches, pp. 403-415, Springer-Verlag, Berlin.

Anizoba, E.C., Okereke, I.E. \& Nganwuchu, G.C., 2020, 'Students' perception of mystical and pathogenic agents of disease causation in Enugu State Nigeria', UJAH: UNIZIK Journal of Arts and Humanities 12(1), 199-228. https://doi.org/10.4314/ ujah.v21i1.9

Baxter, A.G., 2001, 'Louis Pasteur's beer of revenge', Nature Reviews Immunology 1(12), 229-232. https://doi.org/10.1038/35105083

Bouyer, L., 1981, 'Mysticism: An essay on the history of the word', in R. Woods (ed.), Understanding mysticism, Doubleday, Garden City, NY.
Brock, T.D., 1999, Koch Robert: A life in medicine and bacteriology, ASM Press, Washington, DC.

Christopher, E., 1989, 'Religion and social change: The case of the Igbo of Nigeria', NeuZeitschrift Fun Missionwissenschaft (NZM) 4(2), 112-120.

Egger, 2008, In search of a germ theory equivalent for chronic disease, Australia Southern Cross University, East Lismore.

Essien, E.D., 2014, 'Toward an empirical inquiry of religious language in the interface of libation rituals in Africa: Experience from Ibibio, Nigeria', Advances in Socia Sciences Research Journal 1(6), 129-141. https://doi.org/10.14738/assrj.16.521

Etobe, E.I., 2002, Sociology of health and rehabilitation, Baye Communications Ltd., Calabar.

Farber, D., 2014, From germ theory to global warming, science denialism is beyond parody, Science \& Technology, Berkeley, viewed 29 May 2018, from https://blogs. berkeley.edu/2014/08/27/from-germ-theory-to-global-warming-sciencedenialism-is-beyond-parody/.

Fenner, F. \& Gibbs, A. (eds.), 1988, Portraits of viruses: A history of virology, Karger, Basel.

Fielder, J.L., 2001, Handbook of nature cure volume one: Nature cure vs. medical science: Chapter one: That fallacious germ theory, viewed 30 May 2018, from https://chestofbooks.com/health/natural-cure/John-L-Fielder/Handbook-ofNature-Cure-Vol1/Chapter-One-That-Fallacious-Germ-Theory.html.

Frazer, J.G., 1992, The golden bough, Macmillan, New York, NY.

Henderson, D.A. \& Brock, T.D., 1999, Smallpox and vaccinia, Vaccines, Saunders Company, New York, NY.

Idowu, E., 2001, African traditional religion: A definition, The White Friars Press, London. Ilogu, E., 1987, Christianity and Igbo culture, Nok Publishers Ltd., New York, NY. Jantzen, G.M., 1994, 'Feminists, philosophers, and mystics', Hypatia 9, 186-206.

Last, J.M., 2007, Miasma theory: A dictionary of public health, Oxford University Press, Westminster College, PA.

Madigan, M.T. \& Martinko, J.M., 2006, Brock biology of micro-organisms, Prentice Hall, Hoboken, NJ.

Madu, J.E., 1996, Fundamentals of religious studies, Franedoh Publishers (Nig) Ltd., Calabar.

Maher, B., 2009, International skeptics forum-view single post - Bill Maher says vaccines don't present disease, viewed 30 May 2018, from https://www.huffpost. com/entry/bill-maher-vaccines_n_5dbdd430e4b0576b62a2d175.

Ngong, D.T., 2009, 'Salvation and materialism in African theology', Studies in World Christianity 15(1), 1-21.

Nutton, V., 1983, 'The seeds of disease: An explanation of contagion and infection from the Greeks to the Renaissance', Medical History 27(1), 1-34. https://doi. org/10.1017/S0025727300042241

Omoregbe, J.I., 1999, Comparative religion Christianity and other world religions in dialogue, Joja Educational Research and Publishers Ltd., Lagos.

Porter, R., 1997, The greatest benefit to mankind: A medical history of humanity, Luckyard, New York, NY.

Radford, B., 2010, Beliefs in witchcraft widespread in Africa, Penquin Books, London.

Turner, D., 1996, The darkness of God: Negativity in Christian mysticism, Cambridge University Press, Cambridge.

Vander-Zanden, W., 1990, The social experience: An introduction to sociology, McGraw-Hill Inc., New York, NY.

Wallach, J.D., Lan, M.A. \& Schrauzer, G.N., 2014, Epigenetics: The death of the genetic theory of disease transmission, SelectBooks, New York, NY.

Waller, J., 2004, The discovery of the germ, Icon, London.

Wehmeier, G., 2000, Oxford advanced learners dictionary, 16th edn., Oxford, New York, NY.

Worboys, M., 2008, Spreading germs: Disease theories and medical practice in Britain 1865-1900, Cambridge University, Cambridge.

World Health Organization (WHO), 1946, Constitution, viewed 04 January 2020, from https://www.who.int/about/governance/constitution. 